\title{
Childhood asthma: what is it and where is it going?
}

Increases in childhood asthma have become a major public health concern. The last 20 years have seen significant rises in the prevalence of wheezing, ${ }^{1}$ exercise-induced peak flow variability, ${ }^{2}$ and asthma diagnosis ${ }^{3}$ in several western countries. ${ }^{45}$ Many studies have shown lower respiratory symptoms, principally wheeze and cough, to be common throughout childhood, from infancy ${ }^{6}$ through school age ${ }^{1}$ to adolescence. ${ }^{78}$ Better understanding of the aetiology of childhood lower respiratory illness will have important consequences for the response to these changes. Despite its high prevalence it is still not possible to define "childhood asthma" satisfactorily, ${ }^{9}$ and there is some danger that asthma may become a generic term for the majority of recurrent lower respiratory illnesses of children which could hinder further understanding of the underlying causes and consequences of this common problem.

\section{Wheezing illness in infancy and early childhood}

Although it is widely assumed that atopy explains the majority of lower respiratory illness (LRI) in childhood there is a growing body of evidence that such illness, particularly in infancy and early childhood, represents a heterogeneous group of syndromes. ${ }^{10}$ Several studies have failed to demonstrate a positive association between markers of atopy in the first two years of life and wheezing illness. A large community based prospective study in Tucson, Arizona, USA has shown an inverse relationship between IgE levels in cord blood and wheezing illness in the first two years of life, although this relationship was reversed in the third year of life. ${ }^{11}$ Further follow up of this group has shown no association between transient early wheezing before the age of three and family history of atopy, increased serum total IgE, or skin test positivity at age six. In contrast, persistent wheezing or wheezing developing after the age of three were significantly associated with a personal or family history of atopy. ${ }^{12}$ Similar outcomes have been demonstrated using other features characteristic of atopy. No relationship between wheezing illness and atopy assessed by skin prick testing or clinical history was demonstrated in two groups of infants and young children identified following hospital admission for wheezing illness. ${ }^{1314}$ Follow up to age 11 of a birth cohort with at least one atopic parent showed a significantly lower prevalence of continuing symptoms or positive skin tests in children with onset of wheezing before the age of two than those with onset thereafter. ${ }^{15}$

Quite apart from the relationship between atopy and wheezing illness, it has been suggested that genetic or intrauterine environmental determinants of airway size and function may influence the later development of wheezing illness. ${ }^{10}$ Prospective studies have suggested that wheezing illness in early infancy is related to indices of tidal airflow reflecting reduced airway calibre, ${ }^{16}$ and low maximal flow at functional residual capacity (VmaxFRC), ${ }^{121718}$ a marker of impaired small airway function. Reduced VmaxFRC has also been found in recurrently wheezy infants. ${ }^{19}$ Airways hyperresponsiveness to methacholine, as measured by reduction in VmaxFRC, is common in infancy and is unrelated to wheezing symptoms. ${ }^{1419}$ These findings point to significant differences between virus-associated wheeze in infancy, in which small but significant impairment of airway function appears to be a major determinant, and asthma in later childhood where atopy and airways hyperresponsiveness are common features. Neither atopy, assessed by any one of several markers, nor airways hyperresponsiveness appears to be a significant determinant of wheezing illness in infancy; indeed, it has been argued that wheezing illness in this group represents a disease distinct from asthma. ${ }^{20}$ Such distinctions would be valuable if they carried clear therapeutic, prognostic, or aetiological implications. There is some evidence to suggest that attempting to identify separate childhood "asthma" syndromes may meet these criteria.

\section{Outcomes of viral wheezing illness in infancy}

There is obvious scope for diagnostic and functional overlap between children with virus-associated wheeze and asthma, and follow up studies have not clearly distinguished between these broad groups although there is a trend towards better prognosis with earlier onset of wheeze in some, but not all, studies. ${ }^{21-24}$ A follow up study to early middle age has shown a better prognosis for those children with a clinical diagnosis of "wheezy bronchitis" than those with asthma, ${ }^{25}$ although none of the existing long term follow up studies recruited children sufficiently young to provide unambiguous identification of asthma and virusassociated wheeze. Other evidence is available from studies of long term outcome in viral-induced bronchiolitis, a common clinical syndrome in infancy usually caused by the respiratory syncytial virus (RSV). Over $95 \%$ of children are infected with RSV before the age of two, usually during the winter, although only $40 \%$ suffer lower respiratory infection and less than $1 \%$ require admission to hospital. ${ }^{26}$ Follow up at age 10 of children admitted with proven RSV infection before the age of two has shown continuing symptoms and an excess of exercise- or histamine-induced airway hyperresponsiveness, but no excess of atopy, compared with controls. ${ }^{27}$ Children infected in infancy with RSV had poorer baseline lung function at age 10, even amongst those without continuing symptoms. Recent work has confirmed bronchiolitis as a risk factor for continuing respiratory morbidity and airways hyperresponsiveness independent of atopy. ${ }^{28}$

The degree to which outcome in bronchiolitis reflects outcome after other viral infections in infancy is unclear. ${ }^{29}$ Martinez et al have shown lower levels of VmaxFRC at age six in children with a history of transient early wheezing, independent of atopy. ${ }^{12}$ Significantly lower levels of small airways function have also been demonstrated in nonatopic school age boys with a history of recurrent wheezing lower respiratory infection. ${ }^{30}$ In addition, hyperresponsiveness to cold air challenge in school age children with a history of lower respiratory infection has been shown to be independent of atopy. ${ }^{31}$ This suggests persisting abnormalities of lung function, unrelated to atopy, in a wider group of children with viral infection in infancy, as well as the few who require admission to hospital for bronchiolitis. Although the relationship between viral infection and abnormal lung function is not clear, prospective studies in infancy suggest that poor lung function may be an aetiological factor in the genesis of recurrent lower 
respiratory tract symptoms, ${ }^{121618}$ possibly modified further by viral infection.

Furthermore, the evidence suggests that virus-associated wheeze in infancy is associated with continuing symptoms and lung function abnormalities well into mid childhood, and that this syndrome is unrelated to atopy. Although these children show reversible airways obstruction and airways hyperresponsiveness to non-specific stimuli, the lack of association with atopy suggests differences from classical atopic asthma in which allergic airway inflammation is a cardinal feature. ${ }^{32}$ Distinctions between asthma and "wheezy bronchitis" have previously been regarded with caution as liable to result in underdiagnosis and undertreatment of asthma in childhood. ${ }^{3334}$ Nevertheless, the evidence for heterogeneity in wheezing illness in infancy and early childhood is strong and calls for a reappraisal of early childhood "asthma" and the long term consequences of different wheezing syndromes.

\section{Lower respiratory illness in later childhood}

Recurrent wheeze is common in older children ${ }^{35} 36$ and, together with diagnosed asthma and airways hyperresponsiveness, is strongly associated with atopy. ${ }^{3738}$ The prevalence of airways hyperresponsiveness declines between the ages of seven and $12,{ }^{3940}$ whilst the association between more severe atopy, wheeze, and airways hyperresponsiveness strengthens. ${ }^{3941}$ The presence of wheeze, airways hyperresponsiveness, and atopy in effect describes a group with "classical" atopic asthma. ${ }^{4243}$ Studies in Melbourne have shown atopy to be an important determinant of outcome of childhood asthma into early adult life, ${ }^{4445}$ while a family history of atopic disease was associated with poorer outcome in some, ${ }^{4647}$ but not all, ${ }^{48}$ follow up studies into middle age.

The significance of other lower respiratory symptoms and isolated airways hyperresponsiveness in childhood is less clear cut. Cough without wheeze is a common finding in epidemiological studies in childhood and appears to decrease with age. ${ }^{49}$ Recurrent dry cough without wheeze was found in $11.5 \%$ of the 813 nine year old New Zealand children studied by Sears et al. ${ }^{50}$ Frequent non-wheezy cough was reported by $4.5 \%$ of eight year olds and $2.3 \%$ of 12 year olds in Queensland, ${ }^{51}$ whilst Holgate and colleagues have shown high levels of cough without wheeze in Southampton. ${ }^{52}$ Although cough alone has been described as a feature of asthma and has been shown to be responsive to antiasthma treatment in several small, highly selected groups, ${ }^{54-56}$ it is not clear whether these symptoms in the community form part of the same syndrome. ${ }^{5457}$ Airways hyperresponsiveness has been advanced as an important feature of "cough variant asthma", 58 although only $24 \%$ of the subjects with cough alone studied by Sears et al had airways hyperresponsiveness. ${ }^{50}$ No association between cough and atopy or airways hyperresponsiveness was observed by Holgate and colleagues after correcting for wheeze, an observation which led them to question the epidemiological relevance of cough as a diagnostic feature of asthma. ${ }^{49}$ The same group has shown wheeze to be associated with increased levels of airways hyperresponsiveness, greater variability in peak expiratory flow rate (PEFR), and greater chronicity of symptoms compared with cough in a selected group of 7-8 year olds followed intensively over one year. ${ }^{53}$ Atopy was associated with increased airways hyperresponsiveness and PEFR variability in this group, but had no effect on the frequency, duration, or magnitude of episodes of respiratory morbidity assessed by falls in PEFR, many of which appeared to be of viral aetiology. ${ }^{59}$ The epidemiological evidence, which also shows approximately equal sex ratios for cough, in contrast to the male preponderance of wheeze, suggests that there are important differences in the determinants of recurrent cough alone and wheeze in this age group.

\section{"Lumping" and "splitting"}

The lack of association between cough without wheeze and atopy or airways hyperresponsiveness raises questions as to whether this group should be considered alongside those children with wheeze, atopy, and airways hyperresponsiveness. There is evidence that maternal history of bronchitis is a more significant risk factor for non-wheezy cough than parental history of asthma. ${ }^{51}$ Persistent cough may reflect an increased susceptibility to viral respiratory infection, which may have a heritable component. It is intriguing to speculate whether this susceptibility involves mechanisms related to those involved in virus-associated wheeze in infancy, and to what extent the two groups of children with virus-associated wheeze in infancy and cough in later childhood may be linked, or even the same. Although the short to medium term prognosis for those with cough alone appears to be good, ${ }^{60}$ the longer term implications of this pattern of lower respiratory illness (which may previously have been described as "bronchitis" or "pneumonia") for the development of adult obstructive lung disease may be less favourable. ${ }^{6162}$ Such children may be at increased risk not only from viral infection but also from other environmental factors such as passive smoking ${ }^{63}$ or air pollution.

The decline in airways hyperresponsiveness may indicate a subgroup of children in which airways hyperresponsiveness associated with lung function abnormalities and sensitivity to viral infection rather than atopy becomes less obvious as the lung matures. Indeed, airways hyperresponsiveness unrelated to symptoms or atopy is common among 7-9 year olds, ${ }^{37}$ while mild degrees of airways hyperresponsiveness have been shown to be unrelated to persisting symptoms or atopy over the age range $8-14 .^{39}$ Slower rates of growth of forced expiratory flow between $25 \%$ and $75 \%$ of vital capacity. $\left(\mathrm{FEF}_{25-75}\right)$ and forced expiratory volume in one second $\left(\mathrm{FEV}_{1}\right)$ have also been observed in inconsistent responders to cold air challenge compared with controls over a similar age span. ${ }^{64}$ Lung function has also been shown to be an independent predictor of airways hyperresponsiveness in both children ${ }^{4165}$ and adults. ${ }^{66}$ Others have found a high degree of tracking in the development of lung function in low birth weight children from ages one to nine. ${ }^{67}$ Given the importance of airway function in predisposing infants to wheezing illness, it may be that reduced airway calibre and viral infection interact to produce continuing susceptibility to respiratory symptoms and airways hyperresponsiveness which is independent of atopy and which gradually resolves with lung growth and maturation.

\section{Causes and consequences}

If abnormalities of lung function are major determinants of significant childhood respiratory morbidity, what factors may influence this? Maternal smoking, particularly in pregnancy, has been shown to be related to decreased lung function in children ${ }^{68}$ and increased frequency of lower respiratory infection in the first year of life, ${ }^{69}$ and much attention has focused on this as a modifiable risk factor. There is also evidence that other environmental effects may have significant effects on lung growth and development. ${ }^{70}$ Genetic effects may also be important. There is some evidence that a parental history of cough predisposes to frequent cough in children. ${ }^{5171}$ Major genetic effects on lung function have been identified ${ }^{72}$ although the mech- 
anisms are unclear. If poor small airway function and, potentially, abnormal viral responsiveness are important determinants of a significant proportion of childhood respiratory morbidity, it may well be possible to identify genetic and environmental factors that contribute to these effects. The emergence of several loci linked to atopy, ${ }^{73}$ total serum IgE levels, ${ }^{745}$ specific IgE responses ${ }^{76}$ and, perhaps, airways hyperresponsiveness ${ }^{75}$ promises to increase our understanding of the genetic determinants of atopy and its role in respiratory disease. Further prospective studies of well characterised families are likely to help in the identification of heritable and environmental influences on other childhood lower respiratory illness and adult obstructive lung disease.

Increased understanding of the natural history of lower respiratory illness, particularly in childhood, will be of great importance for health services planning. If the significantly increased burden of childhood respiratory illness continues into adulthood in the same, or higher, proportion as has occurred in the past, this will present a major additional burden on resources in a manner similar to that represented by the ever increasing numbers of adults with cystic fibrosis. ${ }^{77}$ Increases in the prevalence of childhood wheeze ${ }^{13}$ and exercise-induced PEFR variability, ${ }^{2}$ together with smaller increases in hayfever symptoms, ${ }^{1}$ possible increases in childhood eczema, ${ }^{78}$ and limited evidence for an increase in the prevalence of atopy ${ }^{7980}$ raise the possibility that a significant increase in atopic disease is occurring. ${ }^{81}$ The association between atopy and more severe, persistent asthma ${ }^{45}$ suggests that, if atopy is increasing, there will be a major additional burden of adult disease in the near future.

Nevertheless, the evidence for an increase in atopy is less convincing than that for recurrent lower respiratory tract symptoms. Other factors including small airway function and viral infection, together with poorly understood genetic and environmental interactions, may have contributed significantly to the increase in childhood lower respiratory morbidity. The interaction between these effects and atopy is likely to be complex but, given the present state of knowledge, the assumption that the present epidemic of lower respiratory tract symptoms in childhood is due entirely to atopic asthma is unsustainable. There is clearly an urgent need to increase our understanding of the determinants of childhood respiratory morbidity in order to facilitate both longer term intervention to reduce morbidity and to anticipate the magnitude of the problems that may affect the adult population in the near future.

Reprint requests to Professor P Helms

Department of Child Health, University of Aberdeen, Foresterhill,

Aberdeen AB9 2ZD,

UK

1 Ninan TK, Russell G. Respiratory symptoms and atopy in Aberdeen schoolchildren: evidence from two surveys 25 years apart. BMF 1992;304:873-5.

2 Burr ML, Butland BK, King S, Vaughan-Williams E. Changes in asthma prevalence: two surveys 15 years apart. Arch Dis Child 1989;64:1452-6.

3 Robertson CF, Heycock E, Bishop J, Nolan T, Olinsky A, Phelan PD. Prevalence of asthma in Melbourne schoolchildren: changes over 26 years. Prevalence of asthma in

4 Haahtela T, Lindholm H, Bjorksten F, Koskenvuo K, Laitinen LA. Prevaahtela $T$, Lindholm H, Bjorksten F, Koskenvuo K, Laitinen LA.

5 Laor A, Cohen L, Danon YL. Effects of time, sex, ethnic origin, and area of residence on prevalence of asthma in Israeli adolescents. BMF 1993; 307:841-4.

6 Luyt DK, Burton PR, Simpson H. Epidemiological study of wheeze, doctor diagnosed asthma and cough in preschool children in Leicestershire. $B M \mathcal{J}$ 1993;306:1386-90.

7 Anderson HR, Pottier AC, Strachan DP. Asthma from birth to age 23: incidence and relation to prior and concurrent atopic disease. Thorax 1992;47:537-42.

8 Strachan DP, Anderson HR, Limb ES, O’Neill A, Wells N. A national survey of asthma prevalence, severity, and treatment in Great Britain. Arch Dis Child 1994;70:174-8.

9 Warner JO, Gotz M, Landau LI, Levison H, Milner AD, Pedersen S, et al.
Management of asthma: a consensus statement. Arch Dis Child 1989;64: 1065-9.

10 Wilson NM. The significance of early wheezing. Clin Exp Allergy 1994;24: 522-9.

11 Halonen M, Stern D, Taussig LM, Wright A, Ray CG, Martinez FD. The predictive relationship between serum IgE levels at birth and subsequent incidences of lower respiratory illnesses and eczema in infants. Am Rev Respir Dis 1992;146:866-70.

12 Martinez FD, Wright AL, Taussig LM, Holberg CJ, Halonen M, Morgan WJ, et al. Asthma and wheezing in the first six years of life. $N$ Engl $\mathcal{F}$ Med 1995;332:133-8.

13 Young S, Le Souef PN, Gellhoed GC, Stick SM, Turner KJ, Landau LI. The influence of a family history of asthma and parental smoking on airway responsiveness in early infancy. $N$ Engl $\mathcal{F}$ Med 1991;324:1168-73.

14 Wilson NM, Phagoo SB, Silverman M. Atopy, bronchial responsiveness, and symptoms in wheezy 3 year olds. Arch Dis Child 1992;67:491-5.

15 Sporik R, Holgate ST, Cogswell JJ. Natural history of asthma in childhood-a birth cohort study. Arch Dis Child 1991;66:1050-3.

16 Martinez FD, Morgan WJ, Wright AL, Holberg CJ, Taussig LM. Diminished lung function as a predisposing factor for wheezing respiratory illness in infants. $N$ Engl f Med 1988;319:1112-7.

17 Tager IB, Hanrahan JP, Tosteson TD, Castile RG, Brown RW, Weiss ST, et al. Lung function, pre- and post-natal smoke exposure, and wheezing in the first year of life. Am Rev Respir Dis 1993;147:811-7.

18 Young S, O'Keeffe PT, Arnott J, Landau LI. Lung function, airway responsiveness, and respiratory symptoms before and after bronchiolitis. Arch Dis Child 1995;72:16-24.

19 Stick SM, Arnott J, Turner DJ, Young S, Landau LI, Lesouef PN. Bronchial responsiveness and lung function in recurrently wheezy infants. Am Rev Respir Dis 1991;144:1012-5.

20 Silverman $M$. Out of the mouths of babes and sucklings: Lessons from early childhood asthma. Thorax 1993;48:1200-4.

21 Strachan DP. The prevalence and natural history of wheezing in early childhood. $f R$ Coll Gen Pract 1985;35:182-4.

22 Foucard T, Sjoberg O. A prospective 12-year follow-up study of children with wheezy bronchitis. Acta Paediatr Scand 1984;73:577-83.

23 Aberg N, Engstrom I. Natural history of allergic diseases in children. Acta Paediatr Scand 1990;79:206-11.

24 Park ES, Golding J, Carswell F, Stewart-Brown S. Preschool wheezing and prognosis at 10. Arch Dis Child 1986;61:642-6.

25 Godden DJ, Ross S, Abdalla M, McMurray D, Douglas A, Oldman D, et al. Outcome of wheeze in childhood. Symptoms and pulmonary function 25 years later. Am $\mathcal{F}$ Respir Crit Care Med 1994;149:106-12.

26 Isaacs D. Bronchiolitis. BMf 1995;310:4-5.

27 Pullan CR, Hey EN. Wheezing, asthma, and pulmonary dysfunction 10 years after infection with respiratory syncytial virus in infancy. $B M F 1982$; 284:1665-9.

28 Murray M, Webb MS, O'Callaghan C, SwarbrickAS, Milner AD. Respiratory status and allergy after bronchiolitis. Arch Dis Child 1992;67:482-7.

29 Landau LI. Bronchiolitis and asthma: are they related? Thorax 1994;49:2936.

30 Henderson FW, Stewart PW, Burchinal MR, Voter KZ, Strope GL, Irvins SS, et al. Respiratory allergy and the relationship between early childhood lower respiratory illness and subsequent lung function. Am Rev Respir Dis 1992;145:283-90.

31 Weiss ST, Tager IB, Munoz A, Speizer FE. The relationship of respiratory infections in early childhood to the occurrence of increased levels of bronchial responsiveness and atopy. Am Rev Respir Dis 1985;131:573-8.

32 Anonymous. International consensus report on diagnosis and treatment of asthma. National Heart, Lung, and Blood Institute, National Institutes of Health. Eur Respir $\mathcal{f}$ 1992;5:601-41.

33 Speight AN, Lee DA, Hey EN. Underdiagnosis and undertreatment of asthma in childhood. $B M \mp 1983 ; 286: 1253-6$.

34 Speight AN. Is childhood asthma being underdiagnosed and undertreated? BMF 1978;2:331-2.

35 Burrows B, Sears MR, Flannery EM, Herbison GP, Holdaway MD. Relationships of bronchial responsiveness assessed by methacholine to serum IgE, lung function, symptoms, and diagnoses in 11-year-old New Zealand children. $\mathcal{f}$ Allergy Clin Immunol 1992;90:376-85.

36 Salome CM, Peat JK, Britton WJ, Woolcock AJ. Bronchial hyperresponsiveness in two populations of Australian schoolchildren. I. Relation to respiratory symptoms and diagnosed asthma. Clin Allergy 1987;17:27181 .

37 Pattemore PK, Asher MI, Harrison AC, Mitchell EA, Rea HH, Stewart AW. The interrelationship among bronchial hyperresponsiveness, the diagnosis of asthma, and asthma symptoms. Am Rev Respir Dis 1990;142: diagnosis

38 Peat JK, Britton WJ, Salome CM, Woolcock AJ. Bronchial hyperresponsiveness in two populations of Australian schoolchildren. II. Relative
importance of associated factors. Clin Allergy 1987;17:283-90.

39 Peat JL, Salome CM, Sedgwick CS, Kerrebijn J, Woolcock AJ. A prospective study of bronchial hyperresponsive and respiratory symptoms in a population of Australian schoolchildren. Clin Exp Allergy 1989;19:299-306. 40 Clifford RD, Radford M, Howell JB, Holgate ST. Prevalence of atopy schoolchildren. Arch Dis Child 1989;64:1126-32.

41 Sears MR, Burrows B, Herbison GP, Flannery EM, Holdaway MD. Atopy in childhood. III. Relationship with pulmonary function and airway responsiveness. Clin Exp Allergy 1993;23:957-63.

42 Burrows B, Martinez FD, Halonen M, Barbee RA, Cline MG. Association of asthma with serum IgE levels and skin-test reactivity to allergens. $N$ of asthma with serum IgE leve

43 Sears MR, Burrows B, Herbison GP, Holdaway MD, Flannery EM. Atopy in childhood. II. Relationship to airway responsiveness, hay fever and in childhood. II. Relationship to airway

44 Martin AJ, Landau LI, Phelan PD. Natural history of allergy in asthmatic children followed to adult life. Med $\mathcal{f}$ Aust 1981;2:470-4

45 Kelly WJ, Hudson I, Phelan PD, Pain MC, Olinsky A. Atopy in subjects with asthma followed to the age of 28 years. $\mathcal{F}$ Allergy Clin Immunol 1990 85:548-37.

46 Sibbald B, Horn ME, Gregg I. A family study of the genetic basis of asthma and wheezy bronchitis. Arch Dis Child 1980;55:354-7.

47 Jenkins MA, Hopper JL, Bowes G, Carlin JB, Flanders LB, Giles GG. Factors in childhood as predictors of asthma in adult life. $B M \mathcal{F} 1994 ; 309$ 90-3. 
48 Roorda RJ, Gerritsen J, van Aalderen WM, Knol K. Influence of a positive family history and associated allergic diseases on the natural course of asthma. Clin Exp Allergy 1992;22:627-34.

49 Clifford RD, Howell JB, Radford M, Holgate ST. Associations between respiratory symptoms, bronchial response to methacholine, and atopy in respiratory symptoms, bronchial response to methacholine, and atopy

50 Sears MR, Jones DT, Holdaway MD, Hewitt CJ, Flannery EM, Herbison GO, et al. Prevalence of bronchial reactivity to inhaled methacholine in GO, et al. Prevalence of bronchial reactivity to

51 Duffy DI, Mitchell CA. Lower respiratory tract symptoms in Queensland school-children. Risk factors for wheeze, cough and diminished ventilator function. Thorax 1993;48:1021-4.

52 Clifford RD, Radford M, Howell JB, Holgate ST. Prevalence of respiratory symptoms among 7 and 11 year old schoolchildren and association with asthma. Arch Dis Child 1989;64:1118-25.

53 Clough JB, Williams JD, Holgate ST. Effect of atopy on the natural history of symptoms, peak expiratory flow, and bronchial responsiveness in 7 and 8-year-old children with cough and wheeze. A 12-month longitudinal study. Am Rev Respir Dis 1991;143:755-60.

54 Anonymous. Cough and wheeze in asthma: are they interdependent? Lancet 1988; i:447-8.

55 Hannaway PJ, Hoppper GDK. Cough variant asthma in children. $\mathscr{F} A M A$ 1982;247:206-8.

56 Corrao WM, Braman SS, Irwin RS. Chronic cough as the sole presenting manifestation of bronchial asthma. $N$ Engl f Med 1979;300:633-7.

57 McKenzie S. Cough - but is it asthma? Arch Dis Child 1994;70:1-2.

58 O'Connell EJ, Rojas AR, Sachs MI. Cough-type asthma: a review. Ann Allergy 1990;66:278-85.

59 Clough JB, Holgate ST. Episodes of respiratory morbidity in children with cough and wheeze. Am f Respir Crit Care Med 1994;150:48-53.

60 Strachan DP, Anderson HR, Bland JM, Peckham C. Asthma as a link between chest illness in childhood and chronic cough and phlegm in young adults. BMF 1988;292:890-3.

61 Shaheen SO, Barker DJ, Shiell AW, Crocker FJ, Wield GA, Holgate ST The relationship between pneumonia in early childhood and impaired The relationship between pneumonia in early childhood and impaired
lung function in late adult life. Am 7 Respir Crit Care Med 1994;149: lung funct

62 Barker DJ, Godfrey KM, Fall C, Osmond C, Winter PD, Shaheen SO Relation of birth weight and childhood respiratory infection to adult lung function and death from chronic obstructive airways disease. BMF 1991; 303:671-5.

63 Burrows B, Knudson RJ, Cline MG, Lebowitz MD. A reexamination of risk factors for ventilatory impairment. Am Rev Respir Dis 1988;138: 829-36.

64 Redline S, Tager IB, Segal MR, Gold D, Speizer FE, Weiss ST. The relationship between longitudinal change in pulmonary function and nonspecific airway responsiveness in children and young adults. Am Rev Respir Dis 1989;140:179-84.
65 Pattemore PK, Holgate ST. Bronchial hyperresponsiveness and its relationship to asthma in childhood. Clin Exp Allergy 1993;23:886-900.

66 Britton J, Pavord I, Richards K, Knox A, Wisniewski A, Wahedna I, et al. Factors influencing the occurrence of airway hyperreactivity in the general population: the importance of atopy and airway calibre. Eur Respir $\mathscr{f} 1994$; population:

67 Chan KN, Wong YC, Silverman M. Relationship between infant lung mechanics and childhood lung function in children of very low birthweight. Pediatr Pulmonol 1990;8:74-81.

68 Wang X, Wypij D, Gold DR, Speizer FE, Ware JH, Ferris BG, et al. A longitudinal study of the effects of parental smoking on pulmonary function in children 6-18 years. Am f Respir Crit Care Med 1994;149:1420-5.

69 Wright AL, Holberg C, Martinez FD, Taussig LM. Relationship of parental smoking to wheezing and nonwheezing lower respiratory tract illnesses in infancy. Group Health Medical Associates. F Pediatr 1991;118:20714.

70 Helms PJ. Lung growth: implications for the development of disease. Thorax 1994;49:440-1.

71 Camilli AE, Holberg CJ, Wright AL, Taussig LM. Parental childhood respiratory illness and respiratory illness in their infants. Group Health respiratory illness and respiratory illness in their infants.

72 Redline S, Tishler PV, Lewitter FI, Tager IB, Munoz A, Speizer FE. Assessment of genetic and nongenetic influences on pulmonary function. A twin study. Am Rev Respir Dis 1987;135: 217-22.

73 Shirakawa T, Li A, Dubowitz M, Dekker JW, Shaw AE, Faux JA, et al. Association between atopy and variants of the beta subunit of the high-affinity immunoglobulin E receptor. Nature Genetics 1994;7:125-30.

74 Marsh DG, Neely JD, Breazeale DR, Ghosh B, Friedhoff LR, Ehrlich Kautzky E, et al. Linkage analysis of IL-4 and other chromosome $5 \mathrm{q} 31$.1 markers and total serum immunoglobulin $\mathrm{E}$ concentrations. Science 1994; 264:1152-6.

75 Meyers DA, Postma DS, Panhuysen CIM, Xu J, Amelung PJ, Levitt RC et al. Evidence for a locus regulating total serum IgE levels mapping to ct al. Evidence for a locus regulating total

76 Moffatt MF, Hill MR, Cornelis F, Schou C, Faux JA, Young RP, et al Genetic linkage of T-cell receptor alpha/delta complex to specific IgE Genetic linkage of T-cell receptor alp
responses. Lancet 1994;343:1597-600.

77 Elborn JS, Shale DJ, Britton JR. Cystic fibrosis: current survival and population estimates to the year 2000. Thorax 1991;46:881-5.

78 Williams HC. Is the prevalence of atopic dermatitis increasing? Clin Exp Dermatol 1992;17:385-91.

79 Nakagomi T, Itaya H, Tominga T, Yamaki M, Hisamatsu SI, Nakagom O. Is atopy increasing? Lancet $1994 ; 343: 121-2$.

80 Sibbald B, Rink E, D'Souza M. Is the prevalence of atopy increasing? $\mathrm{Br}$ f Gen Pract 1990;40:338-40.

81 Blumenthal M, Bousquet J, Burney P, Burr M, Bryan S, Charpin D, et al. Evidence for an increase in atopic disease and possible causes. Clin Exp Allergy 1993;23:484-92. 